\title{
Nonlinearity Correction in Dynamic Measuring Devices Using Neural Network Models
}

\author{
Laith Al Rawashdeh, Igor Zakharov, Oleg Zaporozhets \\ Kharkiv National University of Radio Electronics, Nauky Ave, 14, Kharkiv, Kharkiv Oblast, Ukraina, 61000
}

\begin{abstract}
A neural network compensator for the nonlinearity of a dynamic measuring instrument is proposed, which allows restoring the value of the measured input signal. The inverse model of a nonlinear dynamic measuring device is implemented based on a three-layer perceptron supplemented by delay lines of input signals. The properties of the proposed neural network compensator are studied through simulation computer modelling using various types of calibration input signals for the training of an artificial neural network.
\end{abstract}

Keywords: artificial neural network, three-layer perceptron, training, inverse model, neural network compensator UIUIU

\section{Introduction}

The advances of modern signal processing can improve measurement accuracy and implement fairly complex measurement procedures. Artificial neural networks are one of the promising areas for the development of intelligent information management and processing technologies. Neural networks are used to solve complex problems that require analytical calculations similar to those made by the human brain, including pattern recognition, classification (clustering), forecasting, approximation, decision making and control, data compression and associative memory.

Currently, there are many studies of neural networks. The works of Wasserman [1], Haykin [2], Rojas [3] described in sufficient detail the theoretical foundations of neural networks and practical recommendations for their use. The main advantages of neural networks over traditional computational methods are the ability to learn, adapt to environmental changes, the flexibility of the structure, fault tolerance.Neural networks are also an essential tool for machine learning in artificial intelligence [4].

Recently, neural network technologies are increasingly being used in measurement practice. The development of neural network dynamic models of measuring devices is one of the promising areas of intellectualization of modern measurement technology. Such models significantly improve the metrological characteristics and efficiency of existing nonlinear dynamic measuring transducers [5-7]. The use of neural network dynamic models allows the creation of intelligent measuring devices

Autor korespondujący:

Laith Al Rawashdeh, laithbkoor@yahoo.com

Artykuł recenzowany

nadesłany 04.09.2020 r., przyjęty do druku 16.11.2020 r. with the ability to individualize their dynamic parameters to external factors and measurement conditions.

\section{Problem statement}

In measurement practice, one often has to deal with dynamic measuring devices having substantially nonlinear characteristics. It is necessary to have an appropriate mathematical model to analyze such objects and study their behaviour. The theoretical analysis allows obtaining a mathematical description in the form of differential equations. Experimental analysis based on observations can result in a parametric or nonparametric model. The most widespread are parametric models that require solving structural and parametric identification problems and have a limited number of parameters.

Let us consider a nonlinear dynamic measuring transducer, generally described by the nonlinear autoregressive equation (NARX model) [8]

$y(t)=$

$=f(y(t-1), y(t-2), \ldots, y(t-n), x(t), x(t-1), \ldots, x(t-m))+\xi(t)$,

where $t=0,1,2, \ldots$ is the discrete time, $y(t)$ is the output signal, $x(t)$ is the input signal, and $\xi(t)$ is the additive random noise reduced to the output, describing the influence of internal and external disturbing factors. The nonlinearity of the conversion function of the measuring chain link is an undesirable property since it introduces an additional error into the measurement result.

A universal method for reducing the nonlinearity of the conversion function is its algorithmic correction using an additional corrector filter. This filter implements theinverserelation to the conversion function (1):

$\hat{x}(t)=$

$=\psi(y(t), y(t-1), \ldots, y(t-n), \hat{x}(t-1), \hat{x}(t-2), \ldots, \hat{x}(t-m))^{\mathrm{T}}$. 
This device, connected in series with the measuring device, allows compensating for its nonlinear dynamics and obtaining an estimate of the measured input signal. An additional condition is the invariance of such a corrector to any nonlinear conversion function.

It is proposed to use a three-layer perceptron supplemented by delay lines of input signals as a corrector that implements the inverse model of a nonlinear measuring device. This choice is justified by the fact that neural networks are nonlinear, have good approximating properties and can be synthesized by training [1-4].

\section{Neural network corrector for the nonlinearity of the dynamic measuring device}

The search for unknown optimal parameters of a neural network model is carried out using the training procedure shown in Fig. 1. As a training sample for adjusting the synaptic weights of the neural network, time sequences of the input and output signals of the nonlinear measuring device are used.

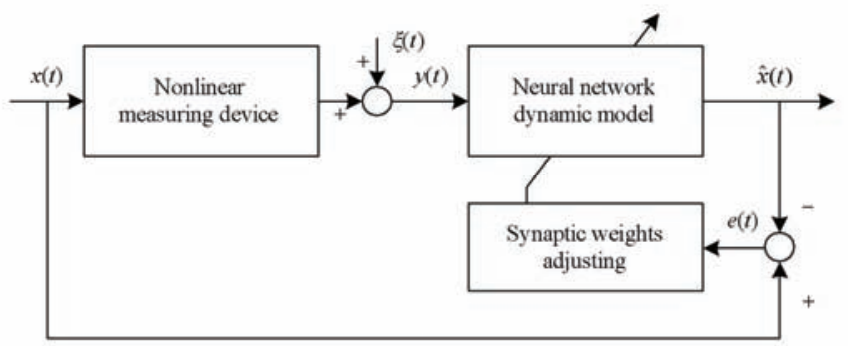

Fig. 1. Training of a neural network model

Rys. 1. Uczenie modelu sieci neuronowej

The signal $x(t)$ is fed to the input of the measuring device, and thenits output signal $y(t)$ is measuredand fed to the input of the neural network model. The output signal of the corrector $\hat{x}(t)$ is compared to the input signal $x(t)$, and the error signal $e(t)=x(t)-\hat{x}(t)$ is generated. This signal is used to adjust the synaptic weights of the neural network model. The adjustment is carried out so that the output signal of the corrector $\hat{x}(t)$ is the best approximation of the input signal of the measuring device $x(t)$. In this case, the optimality criterion is to ensure a minimum of the objective function

$$
J(t)=\frac{1}{2} e^{2}(t)=\frac{1}{2}(x(t)-\hat{x}(t))^{2} .
$$

The neural network corrector is implemented based on a three-layer perceptron supplemented by delay lines of input signals. It is an inverse model of a nonlinear dynamic measuring device. The structure of the dynamic neural network model is shown in Fig. 2.

The output layer of the perceptron is made up of one neuron, which forms a signal as a weighted sum of the output signals of the hidden layer neurons

$$
\hat{x}(t)=\sum_{j=1}^{k} V_{j} O_{j}(t)
$$

where $V_{j}, j=1, \ldots, k$ are the synaptic weights of the output network neuron, and $O_{j}$ are the output signals of the hidden layer neurons.

Neurons with the sigmoid activation functions form the hidden layer. The following equations describe each neuron of this layer:

$$
O_{j}(t)=\frac{1}{1+e^{-S_{j}(t)}}, S_{j}=\sum_{i=1}^{n+m+1} W_{i j} \varphi_{i}(t)
$$

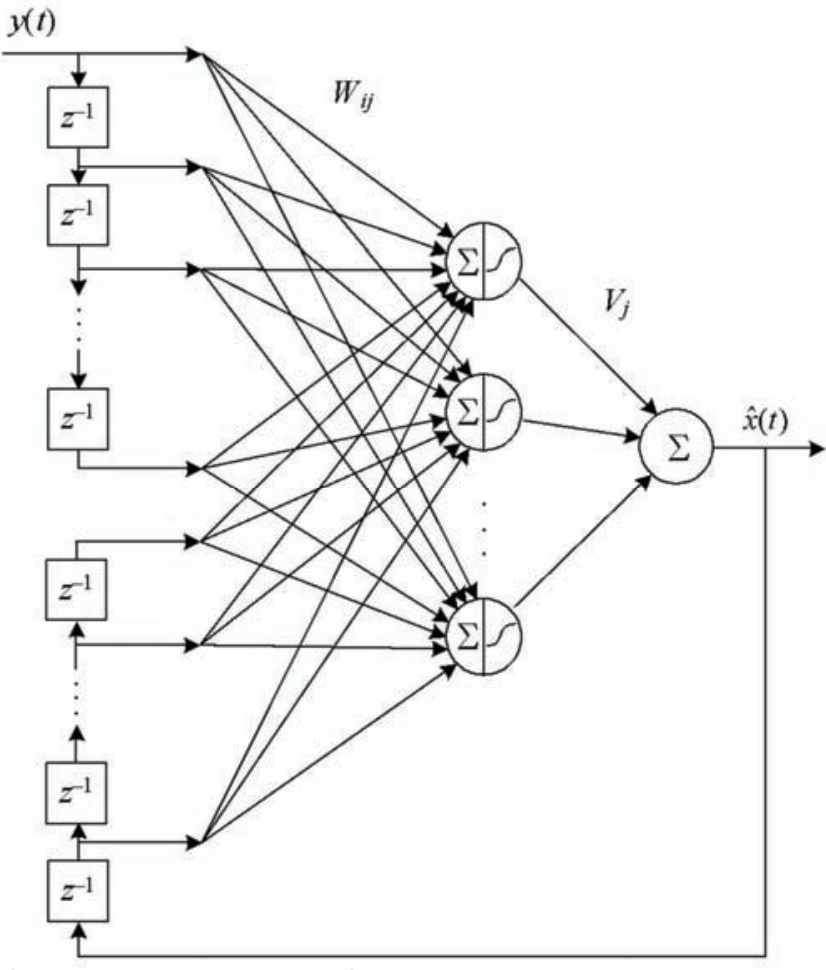

Fig. 2. Structure of the dynamic neural network model Rys. 2. Struktura modelu dynamicznej sieci neuronowej

where $W_{i j}$ is the synaptic weight of the connection of the $i$-th input synapse with the $j$-th neuron of the hidden layer, and $\varphi_{i}(t)$ is the $i$-th component of the vector of input signals of the perceptron.

The vector of input signals of the perceptron with the dimension $((n+m+1) \times 1)$ is described as

$\varphi(t)=(y(t), y(t-1), \ldots, y(t-n), \hat{x}(t-1), \hat{x}(t-2), \ldots, \hat{x}(t-m))^{\mathrm{T}}$.

The neural network training algorithm consists of the following steps:

1. assign random initial values to the synaptic weights of neurons;

2. feed the next sample from the training set $<y(t), x(t)>$ to the input of the neural network;

3. calculate the output signal $\hat{x}(t)$ and the error $e(t)=x(t)-\hat{x}(t)$

4. correct the synaptic weights of neurons using backpropagation $[1-4]$;

5. repeat steps $2-4$ until the value of the objective function (3) becomes sufficiently small or until the number of iterations (learning epochs) reaches the specified value. After that, the training is completed.

\section{Modeling results}

Computer simulation modelling was performed tostudy the proposed inverse neural network model of a nonlinear dynamic measuring device. A three-layer perceptron with sigmoid activation functions in the hidden layer and an adder at the output was used as a neural network. The synaptic weights were adjusted using the Levenberg-Marquardt algorithm, which has a higher speed compared to the gradient descent method. The neural network modelwas trained for 100 epochs. The computer with double CPU $3.3 \mathrm{GHz}$ and $4 \mathrm{~GB}$ of RAM was used for modelling. 
A nonlinear measuring device was modelled by a serial connection of nonlinear static and linear dynamic links (Hammerstein model) described by equations:

$$
\begin{gathered}
x_{n}(t)=5 e^{-0.5 x(t)}, \\
y(t)=y(t-1)-0.5 y(t-2)+0.3 x_{n}(t-1)-0.18 x_{n}(t-2) .
\end{gathered}
$$

The influence of the type of input calibration signal on the training of a neural network model was studied. Samples for the network training were selected by feeding the following calibration signals to the input of the measuring device:

1) pseudo-random white Gaussian noise;

2) periodic sequence of rectangular pulses with a period $T=100$;

3) periodic sequence of triangular pulses with a period $T=100$;

4) sinusoidal signals with different frequencies $x_{1}(t)=\sin (0.05 t) ; x_{2}(t)=\sin (0.1 t) ; x_{3}(t)=\sin (0.5 t) ;$

$5)$ sum of two sinusoidal signals with different frequencies and amplitudes $x(t)=\sin (0.1 t)+0.25 \sin (0.3 t)$;

6) frequency-modulated signal with a linear law of frequency variation.

The standard uncertainty of type A of the signal restored by the corrector was chosen as a criterion of the system efficiency:

$$
u_{A}(\hat{x})=\sqrt{\frac{1}{N-1} \sum_{n=1}^{N}(\hat{x}(n)-x(n))^{2}},
$$

where $N=500$ is the length of the training sample collection.

The results of the modelling, which was carried out for different types of input signals, are presented in Table 1 and Fig. 3.

\section{Conclusions}

The obtained results confirm the operability of the proposed neural network nonlinearity correctorand are entirely consistent with the theoretical assumptions. This opens up vast possibilities for using neural network architectures to solve the problems of inverse modelling of nonlinear dynamic measuring instruments.

An advantage of the proposed approach is the invariance of the neural network model to thetype of nonlinear transformation. A positive factor is also the ability to synthesize the corrector by training without involving complex design methods. This opens up great opportunities for creating intelligent measuring systems with adaptive properties based on the proposed neural network model.

Table 1. Modelling results

Tabela 1. Wyniki modelowania

\begin{tabular}{|c|c|}
\hline Type of input signal & $\begin{array}{c}\text { Standard uncertainty } \\
u_{A}(\hat{x})\end{array}$ \\
\hline Random signal & 0.324 \\
\hline Rectangular impulses with period $T=100$ & 0.352 \\
\hline Triangular impulses with period $T=100$ & 0.155 \\
\hline Sinusoidal signals: & \\
$x_{1}(t)=\sin (0.05 \mathrm{t})$ & 0.030 \\
$x_{2}(t)=\sin (0,1 \mathrm{t})$ & 0.064 \\
$x_{3}(t)=\sin (0.5 \mathrm{t})$ & 0.066 \\
\hline Sum of two sinusoids & \\
$x(t)=\sin (0.1 t)+0.25 \sin (0.3 t)$ & 0.118 \\
\hline Frequency-modulated signal & 0.434 \\
\hline
\end{tabular}

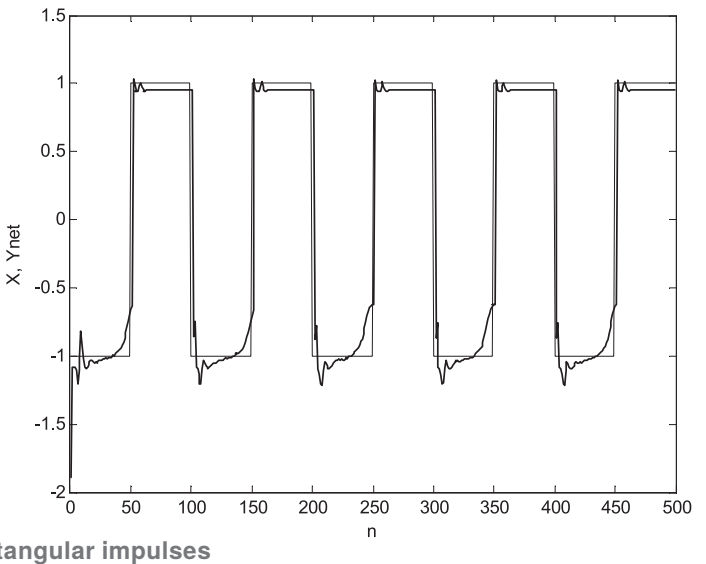

a) rectangular impulse

a) impulsy prostokątne

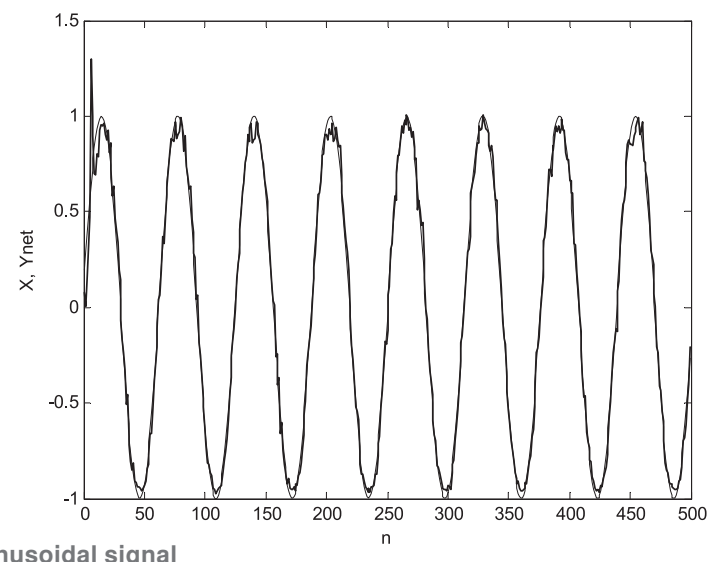

b) sinusoidal signal

b) sygnał sinusoidalny

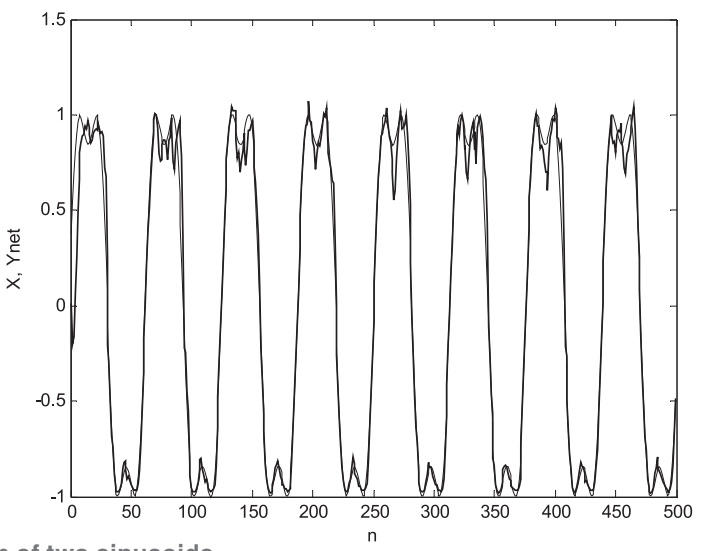

c) sum of two sinusoids

c) suma dwu sinusoid

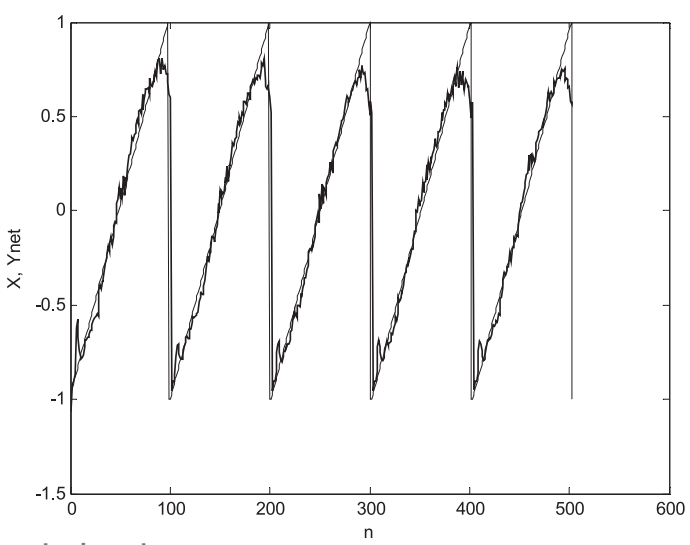

d) triangular impulses

d) impulsy trójkątne

Fig. 3. Input signal and signal restored by the corrector Rys. 3. Sygnał wejściowy I sygnał odtworzony przez korektor 


\section{References}

1. Wasserman P.D., Neural Computing: Theory and Practice, N.Y., Van Nostrand Reinhold, 1989.

2. Haykin S., Neural Networks. A Comprehensive Foundation, New Jersey, Prentice Hall, 2006.

3. Rojas R., Neural Networks: A Systematic Introduction, Springer-Verlag, Berlin 1996.

4. Haykin S., Neural Networks and Learning Machines (3rd Edition), Prentice Hall, 2010.

5. Zaporozhets O.V., Korotenko V.A., Ovcharova T.A., The compensationof the nonlinearity of the measuring devices with artificial neural network, "Systemy upravlinnya, navihatsiyi ta zv'yazku”, Vol. 4 (16), 2010, 99-103, (in Russian).
6. Degtyarov A.V., Zaporozhets O.V., Ovcharova T.A., Adaptive system for the measuring device nonlinearity compensation based on three-layer perceptron, "Elektrotekhnicheskiye i komp'yuternyye sistemy", Vol. 06(82), 2012, 235-241 (in Russian)

7. Degtyarov A.V., Zaporozhets O.V., Ovcharova T.A., Identification of nonlinear dynamic measuring devices with artificial neural network, "Metrolohiya ta prylady", Vol. 2(41), 2013, 85-89 (in Russian)

8. Nelles O., Nonlinear System Identification: from Classical Approaches to Neural Networks and Fuzzy Models, Springer, Berlin 2013.

\section{Korekcja nieliniowości za pomocą modeli sieci neuronowych w zastosowaniu do dynamicznych urządzeń pomiarowych}

Streszczenie: Zaproponowano kompensator sieci neuronowej dla nieliniowości dynamicznego przyrządu pomiarowego, który umożliwia odtworzenie wartości mierzonego sygnału wejściowego. Odwrotny model nieliniowego dynamicznego urządzenia pomiarowego realizowany jest w oparciu o trójwarstwowy perceptron uzupełniony o linie opóźniające sygnałów wejściowych. Właściwości proponowanego kompensatora sieci neuronowej są badane poprzez symulacyjne modelowanie komputerowe z wykorzystaniem różnego rodzaju sygnałów wejściowych kalibracji do uczenia sztucznej sieci neuronowej.

Keywords: sztuczna sieć neuronowa, trójwarstwowy perceptron, uczenie, model odwrotny, kompensator sieci neuronowej

\section{Laith Ahmed Mustafa Al Rawashdeh}

\section{laithbkoor@yahoo.com} ORCID: 0001-7343-7738

Graduated: Automation and Computer- Integrated Technologies Faculty of Ukrainian State Academy of Railway Transport 2006. Postgraduate Student of the Department of Metrology and Technical Expertise of Kharkiv National University of Radio Electronics, Kharkiv, Ukraine. Research interests: dynamic measurements, satellite navigation systems, artificial neural networks.

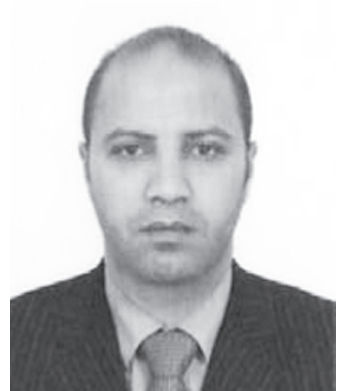

\section{Prof. Igor Petrovitch Zakharov, DSc}

igor.zakharov@nure.ua

ORCID: 0000-0003-3852-4582

Graduated: Radiotechnical Faculty of Kharkiv Institute of Radio Electronics 1978; Postgraduate in Kharkiv National University of Radio Electronics 1981, DSc in metrology and metrology assurance 2006; professor 2007 Professor of the Department of Metrology and Technical Expertise of Kharkiv National University of Radio Electronics (Kharkiv, Ukraine) from 2007 until now. Research inte-

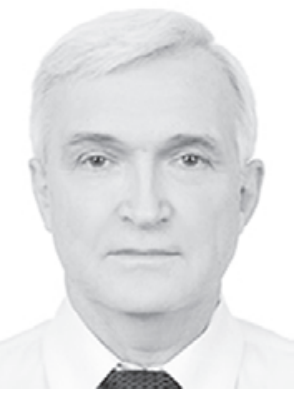
rests: measurement uncertainty dynamic measurement

\section{Oleg Vasyliovych Zaporozhets, PhD}

\section{oleg.zaporozhets@nure.ua} ORCID: 0000-0002-7831-8479

Graduated: Control Systems Faculty of KharkivInstitute of Radio Electronics 1993: Postgraduate in Kharkiv National University of Radio Electronics, PhD in adaptive control systems 1996; docent 2000. Associate Professor (Docent) of the Department of Metrology and Technical Expertise of Kharkiv National University of Radio Elec-

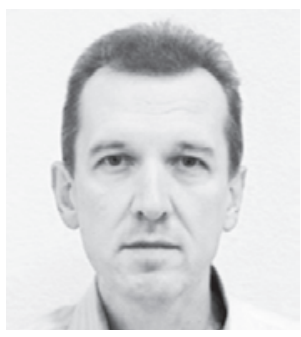

tronics (Kharkiv, Ukraine) from 1997 until now. Research interests: information-measuring systems, adaptive digital signal processing, artificial neural networks. 